\title{
International Convention on
}

the Removal of Wrecks, 2007.

- a New Contribution to the

Safety of Navigation and Marine Environment Protection

\section{Ranka Petrinović, Vesna Skorupan Wolffa, Nikola Mandić, Bisera Plančić}

The text of the International Convention on the Removal of Wrecks was finally adopted at the International Conference held from 14 to 18 May, 2007 in the United Nations Office at Nairobi in Kenya (UNON). The Convention shall enter into force twelve months after having been signed and approved by ten States. The new Convention will provide a legal frame for the States Parties in removing existing and future wrecks located beyond the territorial sea (within their sovereign rights). First of all it is the exclusive economic zone which we discuss in the paper, or if a state has not established the Zone, it is the territory just beyond the territorial seas which extends not more than 200 NM from the starting lines for determining the size of territorial seas. Although the number of maritime accidents has been reduced recently, it has been estimated that there are more than 1300 abandoned wrecks around the world today that pose potential hazards to safe navigation, utilization of the living resources, as well as to the marine environment. In accordance with the United Nations Convention on the Law of the Sea, the Republic of Croatia established Protected Ecological and Fishing Zone comprising sovereign rights characteristic for exclusive economic zones such

University of Split, Faculty of Maritime Studies, Split, Croatia

e-mail: ranka@pfst.hr

a. Adriatic Institute Croatian Academy of Sciences and Arts, Zagreb, Croatia as sovereign right of researching, utilization and conservation of the living resources beyond the outer borders of the territorial sea, as well as their management, and the jurisdiction with regard to the scientific research of the sea and protection and preservation of the marine environment. The Adriatic Sea falls into the category of closed or semi-closed seas by the definition of the United Nation Convention on the Law of the Sea, and therefore if compared with larger seas, the consequences of pollution would be much greater due to its small size.

That is why the adoption of the Convention on the Removal of Wrecks is of great importance to Croatia. The provisions of the Convention oblige the master and the operator of a ship to notify the endangered state party immediately about the accident which may cause a shipwreck, and the state must inform the mariners and other coastal states about the hazard posed by wrecks. The most important fact is that the Convention requires compulsory security for vessels of 300BT. The vessels of 300 BT are obliged to have the certificate of insurance, or some other financial security as a cover for owner's liability for the damage caused by the removal of the wreck.

\section{KEY WORDS}

$\sim$ Removal of wrecks

$\sim$ International convention on the removal of wrecks

$\sim$ Safety of navigation

$\sim$ Marine environment protection 


\section{INTRODUCTION}

The consequences of the pollution within the confines of one state are rarely limited to that state only. The problems regarding the environment cannot be solved by one country alone. Such protection requires an international approach as well as the application of international treaties. It is in this regard that a new international convention on wreck removal was adopted in Nairobi, Kenya on 15th April 2007. ${ }^{(1)}$ It shall enter into force twelve months following the ratification by ten States.(2) This new international convention on wrecks will provide the legal basis for States, Parties to the Convention, to remove shipwrecks that adversely affect the safety of lives and property at sea as well as the marine environment.

The Convention should fill a gap in the existing international maritime legal framework by providing the first set of uniform international rules with the object of ensuring the prompt and effective removal of wrecks located beyond the territorial sea. The new convention also includes the facultative clause which allows the State Parties to apply some provisions of the new Convention to their sovereign area including the territorial sea. Principally, due to its scope of application, this Convention is of special interest to the Republic of Croatia as it has proclaimed a protected ecological and fishing zone which spreads from the outer boarder of the territorial sea in the direction of the offing to the line of delimitation of continental shelf established by the treaty between SFRJ (Socialist Federative Republic of Yugoslavia) and the Italian Republic regarding delimitation of continental shelf, 1968. That zone includes some elements of the exclusive economic zone (Nairobi International Convention on the Removal of Wrecks, 2007).

Although the incidence of marine casualties has decreased dramatically in recent years, mainly thanks to the work of IMO and the unrelenting efforts of Governments and industry to enhance safety in shipping operations, the number of abandoned wrecks is estimated at almost thirteen hundred worldwide. That number might even be greater, and as a result, the problems that the coastal States and shipping in general face have become more acute, which poses a pressing issue.

These problems are three-fold. First, depending on its location, a wreck may constitute a hazard to navigation, potentially endangering other vessels and their crews; second, and of equal concern, depending on its nature, the cargo has the potential for a wreck to cause substantial damage to the marine and coastal environment; and third, in an age where goods and services are becoming increasingly expensive, there is also an issue of the costs involved in the marking and removal of hazardous wrecks. The convention attempts to resolve all of these and other, related, issues (Nairobi International Convention on the Removal of Wrecks, 2007).

\section{CONVENTION DETAILS}

The new Convention provides a sound legal basis for coastal States to remove, or have removed, from their coastlines where they have the sovereign rights or some other exclusive rights, wrecks that pose a hazard to the safety of navigation, or to the marine and coastal environments, or both. It will make shipowners financially liable and require them to take out insurance or provide other financial security for covering the costs of wreck removal. It will also provide the States with a right of direct action against insurers.

The articles in the Convention cover:

- reporting and locating ships and wrecks - covering the reporting of casualties to the nearest coastal State; warnings to mariners and coastal States about the wreck; and action by the coastal State to locate the ship or wreck; criteria for determining the hazard posed by wrecks, including depth of water above the wreck, proximity of shipping routes, traffic density and frequency, type of traffic and vulnerability of port facilities. Environmental criteria such as damage likely to result from the release of cargo, or oil into the marine environment are also included; measures to facilitate the removal of wrecks, including rights and obligations to remove hazardous ships and wrecks - which sets out when the shipowner is responsible for removing the wreck and when a State may intervene;

- liability of the owner for the costs of locating, marking and removing ships and wrecks - the registered shipowner is required to maintain compulsory insurance, or other financial security, to cover liability under the convention; and settlement of disputes. ${ }^{(3)}$
1 The text of the Convention is available at the following Web address: http:// www.official-documents.gov.uk/document/cm82/8243/8243.pdf, visited on 14th Jan 2013. The Croatian translation can be found in "Comparative Maritime Law", year 47 (2008), No 162, pp 152. - 185.

2 The Convention on the Removal of Wrecks has not entered into force to this day. So far, it has been approved only by five states (Bulgaria, India, Iran, Nigeria, Palau), source www.imo.org [accesed 15 October 2012.].
3 http://www.imo.org/about/conventions/listofconventions/pages/nairobiinternational-convention-on-the-removal-of-wrecks.aspx page visited on 14 January 2013. 


\section{CONVENTION APPLICATION SCOPE}

\subsection{Exclusive economic zone as an institute of the International Law of the Sea}

Except as otherwise provided in this Convention, this Convention shall apply to wrecks in the Convention area. (Article 3)

Exclusive economic zones are established by the United Nations Convention on the Law of the Sea, 1982.

According to the international law it is not the part of the State zone, and the coastal state cannot validly put any of its parts under its sovereignty, although the state has the rights, some sovereign rights are mainly economic rights (so called resources rights), and there are some which exceed the nature of resources rights such as protection and preservation of the marine environment, right of hot pursuit etc. On the other hand, the exclusive economic zone is not as the open sea accessible to all coastal or non-coastal states. The rights of the open sea are reduced and also limited in these zones and are practiced in a way that the rights of other states are taken into account as well as the right which a coastal state has in that zone.

The exclusive economic zone is therefore the zone sui generis in which the rights and duties of coastal state, as well as the rights and duties of other states are determined by customary international law. So far, 122 states in the world have proclaimed the exclusive economic zone 200 miles wide (starting from the baseline from which the breadth of the territorial sea is measured so the zone is actually 188 miles wide), and 14 states have proclaimed fishing zones ( 7 states have proclaimed their territorial sea wider than 12 miles, mostly 200 miles) (Barić Punda and Rudolf, 2007).

\subsection{Exclusive economic zone of the Republic of Croatia - Protected ecological and fishing zone (ZERP)}

The Law of the Sea of the Republic of Croatia includes provisions on economic zone in Articles 32-34. The exclusive economic zone of the Republic of Croatia includes marine space from the outer limit of the territorial sea in direction of offing to its outer limit allowed by the international law. According to the United Nations Conference on the Law of the Sea, exclusive economic zone cannot spread out further than 200 miles measured from the baseline for measurement of the breadth of the territorial sea. The exclusive economic zone has to be proclaimed. The Republic of Croatia proclaimed the protected ecological and fishing zone (ZERP) which includes only some of the elements of the exclusive economic zones.

According to The Law of the Sea, the Republic of Croatia in its exclusive economic zone has the sovereign rights for the reasons of the following: a) research and utilization, preservation and management of living and other natural resources; $b$ ) production of energy by use of the sea, sea currents and winds. Entitled institutions of the Republic of Croatia have the right and duty to take all required measures for the purpose of realisation of the rights for research, utilization, protection, preservation and management of living resources in its exclusive economic zone, including the survey, inspection, impounding of foreign vessels and legal actions. In case of impounding, or detaining of a foreign vessel and pronounced penalty, the vessel flag state is immediately informed through diplomatic channels.

During navigation through Croatian exclusive economic zone, a navigating craft is obliged to comply with international regulations and standards as well as Croatian regulations on fighting sea pollution from ships and pollution caused by sinking or submarine activities. During overflight of the Republic of Croatia, airplanes are obliged to comply with international regulations and Croatian regulations on fight against sea pollution from air or by air.

Referring to the provisions on exclusive economic zone in Maritime code and the United Nations Convention on the Law of the Sea, 1982, the Croatian Parliament at its session on 3rd October 2003, reached a Decision on extension of jurisdiction of The Republic of Croatia to the Adriatic Sea. In this Decision the concern was expressed over great endangered condition of living resources in the Adriatic Sea. The Decision also stresses the fact that the Adriatic Sea belongs to the group of closed or semiclosed seas by the definition in the United Nations Convention on the Law of the Sea, 1982 (UNCLOS). Therefore, and due to its small dimensions the consequences of the marine environment pollution would be much greater than in other seas. It must be evident that an accident, as the one of the tanker Prestige, would cause the total devastation of living resources in the Adriatic Sea which would result in great social and economic consequences in the coastal area of entire Adriatic, and also to national economy of the Republic of Croatia as a whole, particularly to Croatian tourism (Grabovac and Petrinović, 2006).

Hoping that expansion of national jurisdiction in the Mediterranean would form the conditions for sustainable fishing, and contribute to effective combat against illegal fishing, confirming sovereign rights and jurisdiction which belongs to the Republic of Croatia, and which is already exercised over its entire continental shelf in compliance with the international law, the Croatian Parliament proclaimed the subject matter of exclusive economic zone. It refers to sovereign rights of research, utilization and preservation of living resources of waters outside the outer limits of the territorial sea, and the management, as well as jurisdiction regarding scientific research of the sea and protection and preservation of the marine environment by which the protected ecological and fishing zone of the Republic of Croatia was proclaimed on 3rd October 2003.

The application of the legal system of the Zone as determined by the Decision on expansion of the jurisdiction 
of the Republic of Croatia on the Adriatic Sea, started twelve months following its establishment i.e. on 3rd October 2004. However, on that day the application of the legal system of the protected ecological and fishing zone of the Republic of Croatia was prolonged for the countries members of the European Union until the conclusion of partnership in fishing between Croatia and European Union is reached.

The decision of 2003 claims the approved rule of the international law that the declared protected ecological and fishing zone of the Republic of Croatia, with Croatian sovereign rights and jurisdiction, remains marine space in which all states are free to navigate, over fly and lay submarine cables and pipelines as guaranteed by the international law and other internationally allowed utilization of the sea. The limits of the ecological and fishing zone have been established. The zone encompasses marine space from the outer limits of the territorial sea in the direction of offing to its outer limits allowed by the general international law. Outer limits of the protected ecological and fishing zone shall be established by the international contracts on delimitation between states whose coasts lay opposite or laterally to Croatian coast. Until these delimitation contracts are concluded, the outer limit of the Zone shall temporarily follow the line of delimitation of continental shelf determined by the treaty between the former Yugoslavia (SFRJ) and the Italian Republic on delimitation in 1968, and in lateral delimitation it shall follow the line which continues and follows the temporary line of the territorial sea delimitation as determined by the Protocol on temporary regime of south border between the Republic of Croatia and Serbia and Montenegro in 2001 (Grabovac and Petrinović, 2006).

The application of the protected ecological and fishing zone does not include all the elements of the exclusive economic zone as in the Convention on the Law of the Sea and Maritime law of the Republic of Croatia. In that zone the sovereign rights are not realised as the rights to produce the energy using the sea, sea currents and winds as well as the rights to construction and application of construction regulations and use of artificial islands, installations and plants on the sea, sea bottom and submarine area.

\subsection{The application of the Convention to the territorial sea of a costal state}

Apart from the application to a costal state's exclusive economic zone, the International Convention on the Removal of Wrecks also includes the facultative clause (Article 3 ) which allows the State Parties to apply some provisions of the Convention to their sovereign area including the territorial sea. A State Party may extend the application of this Convention to wrecks located within its territory, including the territorial sea. In that case, that Party shall notify the Secretary-General accordingly, at the time of expressing its consent to be bound by this Convention, or at any time thereafter.

The UK government, one of the three states that started the issue of international regulation of wreck removal, proposed the application of the provisions of The International Convention on the Removal of Wrecks. The UK proposed the selective application of the provisions in the Convention to their territorial sea as they wanted to maintain existing wreck removal laws applicable in the UK, but also they supported the application of the Convention provisions to compulsory insurance provisions for the vessels that have become wrecks in their own territorial sea (Griggs, 2012).

It is very important that the facultative clause which allows the State Parties to apply some provisions of the new Convention to their territorial sea is included in the Convention as the majority of hazardous wrecks which endanger the safe navigation and the marine environment are situated in that area.

\subsection{Exclusions}

The Convention shall not apply to measures taken under the International Convention relating to Intervention on the High Seas in Cases of Oil Pollution Casualties, 1969, as amended, or the Protocol relating to Intervention on the High Seas in Cases of Pollution by Substances other than Oil, 1973, as amended.

The convention shall not apply to any warship or other ship owned or operated by a State and used, for the time being, only on Government non-commercial service, unless that State decides otherwise.

Where a State Party decides to apply Convention to its warships or other ships as described above, it shall notify the Secretary-General, thereof, specifying the terms and conditions of such application.

The Convention allows the State Party to extend the application of the Convention to its internal waters and territorial sea. ${ }^{(4)}$ In that case, subject to the national law of the Affected State, the registered owner may contract with any salvor or other person to remove the wreck determined to constitute a hazard on behalf of the owner. Before such removal commences, the Affected State may lay down conditions for such removal only to the extent necessary to ensure that the removal proceeds in a manner that is consistent with considerations of safety and protection of the marine environment.

4 In that case, Article 2, paragraph 4, Articles 9, paragraphs 1, 5, 7, 8, 9, and 10, as well as Article 15 of the Convention will not be applied in the territory of the State Party (the internal waters and territorial sea). 


\section{THE SUBJECT OF THE CONVENTION ON THE REMOVAL OF WRECKS}

\subsection{Definition for the purposes of this Convention}

Convention area means the exclusive economic zone of a State Party, established in accordance with international law or, if a State Party has not established such a zone, an area beyond and adjacent to the territorial sea of that State determined by that State in accordance with international law and extending not more than 200 nautical miles from the baselines from which the breadth of its territorial sea is measured.

Ship means a seagoing vessel of any type whatsoever and includes hydrofoil boats, air-cushion vehicles, submersibles, floating craft and Wreck Removal Convention Act 2011 (c. 8) Schedule - Wreck Removal Convention 11 floating platforms, except when such platforms are on location engaged in the exploration, exploitation or production of seabed mineral resources.

Maritime casualty means a collision of ships, stranding or other incident of navigation, or other occurrence on board a ship or external to it, resulting in material damage or imminent threat of material damage to a ship or its cargo.

One of the most important questions asked during the draft of the Convention on the Removal of Wrecks was about the definition of the term "wreck". The question was a subject of many discussions during the long preparation of the draft. According to the convention "wreck" includes a sunken or stranded ship; or any part of a sunken or stranded ship, including any object that is or has been on board such a ship; or any object that is lost at sea from a ship and that is stranded, sunken or adrift at sea. In order for the Convention to include the wrecks which are afloat or parts of wrecks adrift, the definition is extended and it includes "a ship that is about, or may reasonably be expected, to sink or to strand". However in the continuation of the same clause there is a condition that such vessel expected to sink shall not be considered a "wreck" if effective measures to assist the ship are being taken. The term "effective" allows the State party to intervene if it is not satisfied with salvage services in achieving fast and safe wreck removal. In defining the "wreck" the term "ship" is used, however in the Convention this term means a sailing vessel of any type (except warships and non-commercial state vessels), floating craft and platforms if not engaged in exploration, exploitation or production of seabed mineral resources.

The Convention then defines the "hazard" that the wreck represents. Also this term was the subject of many debates while preparing the draft of the Convention. It resulted in the definition that the convention shall be applied only to wrecks which pose danger to navigation or to the marine environment (may reasonably be expected to result in major harmful consequences to the marine environment). In Article 6 there is a list of criteria which should be taken into account by the affected state when determining whether a wreck poses a hazard to navigation or to the marine environment. It includes the type, size and construction of the wreck; depth of the water in the area; tidal range and currents in the area; particularly sensitive sea areas, proximity of shipping routes or established traffic lanes; nature and quantity of the wreck's cargo, the amount and types of oil (such as bunker oil and lubricating oil) on board the wreck and, in particular, the damage likely to result should the cargo or oil be released into the marine environment; prevailing meteorological and hydrographical conditions etc. Only when the Affected State determines that the wreck poses a hazard to the safety of navigation and the marine environment it can take further measures in accordance with the Convention.

Related interests means the interests of a coastal State directly affected or threatened by a wreck, such as: maritime coastal, port and estuarine activities, including fisheries activities, constituting an essential means of livelihood of the persons concerned; tourist attractions and other economic interests of the area concerned; the health of the coastal population and the wellbeing of the area concerned, including conservation of marine living resources and of wildlife; and offshore and underwater infrastructure.

Removal means any form of prevention, mitigation or elimination of the hazard created by a wreck. "Remove", "removed" and "removing" shall be construed accordingly.

Registered owner means the person or persons registered as the owner of the ship or, in the absence of registration, the person or persons owning the ship at the time of the maritime casualty. However, in the case of a ship owned by a State and operated by a company which in that State is registered as the operator of the ship, "registered owner"shall mean such company.

Operator of the ship means the owner of the ship or any other organization or person such as the manager, or the bareboat charterer, who has assumed the responsibility for operation of the ship from the owner of the ship and who, on assuming such responsibility, has agreed to take over all duties and responsibilities established under the International Safety Management Code, as amended.

Affected State means the State in whose Convention area the wreck is located. Wreck Removal Convention Act 2011 (c. 8) Schedule - Wreck Removal Convention 12.

\subsection{Objectives and general principles of the Convention}

A State Party may take measures in accordance with the Convention in relation to the removal of a wreck which poses a hazard in the Convention area. Measures taken by the Affected State shall be proportionate to the hazard. Such measures shall not go beyond what is reasonably necessary to remove a wreck 
which poses a hazard and shall cease as soon as the wreck has been removed; they shall not unnecessarily interfere with the rights and interests of other States including the State of the ship's registry, and of any persons, physical or corporate, concerned.

\section{PARTICULAR MEASURES FOR REMOVAL OF WRECKS}

\subsection{Locating and marking of wrecks}

According to the Convention Article 5, the master and the operator of a ship are required to report to the Affected State without delay about the condition of the ship (location, the type of damage, nature and quantity of cargo etc.) once it has become a wreck according to Convention definition. Upon becoming aware of a wreck, the Affected state is obliged to use all the means to urgently warn mariners and other states concerned of the nature and location of the wreck. The Affected State shall mark the wreck in accordance with internationally approved wreck system.

\subsection{Measures for removal of wrecks}

After the Affected State has determined that the wreck poses a hazard, after it has marked and located the wreck, it is obliged to report to the country of a ship's flag (the state of the ship's registry) as well as the registered owner that the vessel is considered a dangerous wreck; and proceed to consult the State of the ship's registry and other states which might be affected about the measures to be taken in relation to the wreck removal. Article 9 gives the list of measures which need to be taken in removal of dangerous wrecks. In this Article it is clearly determined that the owner of the vessel (wreck) is the person obliged to remove the wreck. The owner can do it with the assistance of salvors. The affected State has significant authorities in relation to removal operations. It is allowed to set the conditions for removal but only to the extent necessary to ensure that the removal proceeds in accordance with requirements for safe navigation and the marine environment protection. Apart from that the Affected State can set a reasonable deadline and conditions to the owner in relation to removal operations. If the registered owner does not remove the wreck within the deadline set, the Affected State may remove the wreck at the owner's expense. The affected State has further rights. If the coastal state estimates that that it is necessary to take actions urgently because of requirements of safety to navigation and the marine environment protection, it can immediately take actions for the removal at the owner's expense. State Parties to the Convention are obliged, in accordance with this provision, to ensure by their national regulations that owners, operators and masters of vessels flying their flag to act in compliance with the Convention requirements and to urgently report to the Affected State about the wreck.
Table 1.

Wreck procedures: measures taken vs. subject obligated to take actions.

\begin{tabular}{lr}
\hline $\begin{array}{l}\text { Measures taken in } \\
\text { wreck procedures }\end{array}$ & $\begin{array}{r}\text { Subjects obliged } \\
\text { to take actions }\end{array}$ \\
\hline Reporting wrecks & $\begin{array}{r}\text { The master and the } \\
\text { operator of a ship }\end{array}$ \\
\hline $\begin{array}{l}\text { Warning mariners and } \\
\text { the States concerned }\end{array}$ & Affected State \\
\hline Determination of hazard & Affected State \\
\hline Locating wrecks & Affected State \\
\hline Marking of wrecks & Affected State \\
\hline Removal of wrecks & Registered owner \\
\hline
\end{tabular}

\section{REMOVAL OF WRECKS}

\subsection{Liability of the owner}

The registered owner is liable for the costs of locating, marking and removing the wreck unless the registered owner proves that the maritime casualty that caused the wreck: resulted from an act of war, hostilities, civil war, insurrection, or a natural phenomenon of an exceptional, inevitable and irresistible character; (was wholly caused by an act or omission done with intent to cause damage by a third party; or (c) was wholly caused by the negligence or other wrongful act of any Government or other authority responsible for the maintenance of lights or other navigational aids in the exercise of that function.

Nothing in this Convention shall affect the right of the registered owner to limit liability under any applicable national or international regime, such as the Convention on Limitation of Liability for Maritime Claims, 1976, as amended. No claim for the costs may be made against the registered owner otherwise than in accordance with the provision of the Convention.

\section{COMPULSORY INSURANCE OR OTHER FINANCIAL SECURITY}

The registered owner of a ship of 300 gross tonnage and above, flying the flag of a State Party is required to maintain insurance or other financial security, such as a guarantee of a bank or similar institution, to cover liability under this Convention in an amount equal to the limits of liability under the applicable national or international limitation regime, but in all cases not exceeding an amount calculated in accordance with article 6(1) 
(b) of the Convention on Limitation of Liability for Maritime Claims, 1976, as amended.

A certificate attesting that insurance or other financial security is in force in accordance with the provisions of this Convention shall be issued to each ship of 300 gross tonnage and above by the appropriate authority of the State of the ship's registry after determining that the requirements of the Convention have been complied with. With respect to a ship registered in a State Party, such certificate shall be issued or certified by the appropriate authority of the State of the ship's registry; with respect to a ship not registered in a State Party it may be issued or certified by the appropriate authority of any State Party. This compulsory insurance certificate shall be in the form of the model set out in the annex to this Convention.

A state party may authorize either an institution or an organization recognized by it to issue the certificates. Such institution or organization shall inform that State of the issue of each certificate. In all cases, the State party shall fully guarantee the completeness and accuracy of the certificate so issued and shall undertake to ensure the necessary arrangements to satisfy this obligation.

The Convention provides that any claim based on provisions of this Convention can be made directly to the insurer i.e. guarantee provider. This allows the Affected State and other persons who have suffered the damage to realise their compensation claim in a timely and less complicated manner.

\section{CONCLUSIONS}

The latest international convention in the field of maritime law adopted in Nairobi in May 2007 titled the International Convention on the Removal of Wrecks is an addition to the existing maritime law and international system of safe navigation and protection of the marine environment. Certain provisions show that it is an addition and continuation of other international conventions such as: the International Convention on Civil Liability for Oil Pollution Damage, 1992, the International Convention on Liability and Compensation for Damage in Connection with the Carriage of Hazardous and Noxious Substances by Sea, 1996, the Convention on Third Party Liability in the Field of Nuclear Energy, 1960, the Vienna Convention on Civil Liability for Nuclear Damage, 1963, as amended; or national law governing or prohibiting limitation of liability for nuclear damage; the International Convention on Civil Liability for Bunker Oil Pollution Damage, 2001, as amended.

However, the latest Convention does not lie only on the existing maritime law regulations. In its preamble it evokes the most important international maritime law contract, the United Nation Convention on the Law of the Sea, 1982. The application scope of the International Convention on the Removal of Wrecks is the exclusive economic zone of the Affected State, an institute defined by the United Nations Convention on the Law of the Sea. Further it is provided that the disputes arisen from the provisions of the Convention shall be resolved by the application of provisions relating to the settlement of disputes set out in Part XV of the United nations Convention on the Law of the Sea, 1982, whether or not the States Party to the dispute are also States Parties to the UN Convention on the Law of the Sea, 1982.

Regardless of the fact that the Convention is in a dependent relation with other international contracts of maritime law and The Law of the Sea in the conclusion we must say that the international community needed an international contract in its fight against the marine environment pollution, and in achieving the best standards in the safety of navigation. The International Convention on the Removal of Wrecks should have been adopted much earlier. It will certainly fill the gaps left by other international contracts in disputes of costal states, but also the whole international community, with dangerous and harmful wrecks of which there was said to be over 1300 in the world today and probably many more. The number includes only the wrecks that pose hazard for the safety of navigation and the marine environment. According to historical and archaeological data, only on the seabed in the Croatian part of the Adriatic there are over 15,000 of wrecks of various sizes and purposes. For a small number of these wrecks there is exact information about locations and most of them do not pose a hazard to navigation or the marine environment. But being aware of the future wrecks (the last actual danger to the Adriatic was in February 2008 by the Turkish vessel the Und Adryatic) we welcome the adoption of this Convention hoping that the required number of ten (10) States shall ratify The International Convention on the Removal of Wrecks in a very near future in order to secure sufficient funds for the battle with dangerous wrecks.

\section{REFERENCES}

Barić - Punda, V. and Rudolf, D., (2007), Pravo mora, Split: Pravni fakultet Sveučilišta u Splitu.

Grabovac, I. and Petrinović, R., (2006), Pomorsko pravo - pomorsko javno, upravno i radno pravo, Split: Sveučilište u Splitu - Pomorski Fakultet.

Griggs, P., Draft wreck removal convention (DWRC), available at: http://www.docstoc. com/docs/22789328/13GRIGGS-Draft-Wreck-Removal-Convetion [accessed 11 October 2012.].

Nairobi International Convention on the Removal of Wrecks, (2007), available at: http://www.archive.basel.int/ships/abandonment/wrc.pdf [accessed 11 October 2012.].

Pomorski zakonik Republike Hrvatske, Narodne novine, br. 181/04, 76/07, 146/08 i $61 / 11$. 